УДК 81 '42

DOI: 10.33184/YVDK-2021-04-30.67

Ю.С. Ясакова (асn. БашГУ, г. Уфа)

\title{
ЯЗЫКОВАЯ ИГРА В ИНАУГУРАЦИОННОЙ РЕЧИ ДЖОЗЕФА БАЙДЕНА
}

B cтатье рассматривается языковая игра в инаугурационной речи Джозефа Байдена. Автор приводит различные определения термина «языковая игра», сформулированные отечественными и зарубежными лингвистами, а также изучает особенности языковой игры в инаугурационной речи новоизбранного президента США.

Ключевые слова: языковая игра, языковая норма, инаугурачионная речь, метафора, политический дискурс, предвыборный дискурс, стилистика, лингвистика

The article studies language play in the Joseph Biden's inauguration speech. The author reviews different definitions of the term "language play" proposed by Russian and foreign linguists and analyzes special aspects of the language play in the inauguration speech of the $46^{\text {th }}$ President of the USA.

Key Words: language play, language norm, inauguration speech, metaphor, political discourse, election discourse, stylistics, linguistics

Языковая игра представляет собой яркий и интересный феномен, который уже много лет привлекает внимание исследователей. Данное явление можно встретить во всех сферах словесности: в художественной и научной литературе, разговорной речи, публицистике, рекламных текстах и даже в политическом дискурсе.

В данной статье рассматривается языковая игра в американском политическом дискурсе на материале инаугурационной речи 46-ого президента США Джозефа Байдена. Актуальность данного исследования обусловлена тем, что использование языковой игры в политических выступлениях такого масштаба является эффективным орудием воздействия и 
позволяет моделировать эмоциональное состояние адресанта, а изучение данного явления помогает рассмотреть языковую личность новоизбранного президента и его лингвокреативные возможности.

Одним из первых о сравнении языка и игры заговорил родоначальник структурной лингвистики Фердинанд де Соссюр. Он сравнивал язык с игрой в шахматы, поскольку для них свойственны определенные правила, а изменение отдельных элементов сказывается на всей системе.

Понятие «языковая игра» впервые прозвучало в работе Людвига Витгенштейна под названием «Философские исследования». Он говорил, что весь процесс употребления слов в языке можно представить в виде игр, которые используют дети при овладении родным языком [Витгенштейн 1994: 5]. Именно такие игры и называются языковыми, они включают в себя мысли о предмете, повторение слов за кем-то, наименование предметов и так далее. Таким образом, Л. Витгенштейн утверждал, что любая речевая деятельность является языковой игрой. В такой трактовке явление языковой игры сближается с понятием языковой способности или языковой компетенции [Гридина 1996: 21]

Среди зарубежных исследователей можно также отметить работы Питера Фарба и Дэвида Кристала. Первый из них считал, что языковая игра используется, чтобы уговорить или убедить, показать публике свою мудрость, завоевать почет или уважение. Он говорил, что языковая игра является не развлечением, а серьезным вопросом в жизни, поэтому не ограничивается загадками, каламбурами, шутками и словесными дуэлями. Например, большинство политических слоганов являются языковой игрой. Среди самых известных Питер Фарб отмечает знаменитое выражение Юлия Цезаря «Veni, vidi, vici», запоминающееся благодаря звуковому символизму и краткости. Настоящая языковая игра требует лингвистической виртуозности говорящего в рамках языковых правил [Фарб 1974: 117].

Дэвид Кристал в своей работе «Языковая игра» («Language play») 1998 года выделяет людическую функцию языковой игры. «Мы берем слово, фразу, предложение, часть слова, несколько звуков или букв и заставляем их делать то, что они обычно не делают» - пишет Дэвид Кристал. Он подчеркивает 
тот факт, что мы нарушаем языковые нормы для развлечения. [Кристал 2001: 6]

Похожие определения можно встретить и у отечественных лингвистов. С.Ж. Нухов писал, что языковая игра является следствием стремления человека (homo ludens) к игре. Данное стремление приводит в движение творческие способности человека [Нухов 2016: 16].

T.A. Гридина выдвигает ассоциативную концепцию языковой игры и рассматривает ее как форму лингвокреативного мышления, которое понимается как тип словесного мышления, когда человек использует уже имеющийся знак для реализации его ассоциативного потенциала. Языковая игра нацелена на творчество, которое проявляется в том, что слово трансформируется и интерпретируется с помощью различных лингвистических приемов [Гридина 1996: 29].

Существуют и более узкие подходы к данному явлению. Например, В.3. Санников сравнивает понятие языковой игры с языковой шуткой. Он отмечает, что основная функция языковой игры - достижение комического эффекта [Санников 2002: 13].

В данной статье понятие языковой игры не будет сужаться до смежных понятий «языковой шутки» или «каламбура», поскольку в политическом дискурсе отклонения от языковой нормы используются в основном для привлечения внимания, а не достижения комического эффекта. Под языковой игрой понимается такое явление, когда адресат нарушает системные отношения языка, проявляя тем самым свои лингвокреативные способности. Следовательно, к данному явлению можно отнести не только языковую шутку и каламбур, но также любые средства языковой выразительности, в которых порождаются иные, чем в норме и узусе, способы выражения.

Инаугурационная речь Джозефа Байдена прозвучала с трибуны 20 января 2021 года и в ней можно обнаружить множество примеров, где встречается языковая игра.

Чаще других звучала тема единства нации. Говоря о ней, политик использует:

Метафоры и эпитеты: 1) the most elusive of all things in a democracy - unity 2) as we look ahead in our uniquely American way, restless, bold, optimistic, 3) unity can sound to some like a foolish fantasy. 
Различные параллельные конструкции: with unity we can do great things, important things. We can right wrongs, we can put people to work in good jobs, we can teach our children in safe schools. We can overcome the deadly virus, we can rebuild work, we can rebuild the middle class and make work secure, we can secure racial justice and we can make America once again the leading force for good in the world.

Анафорический повтор словосочетания «we will» делает акцент на вовлеченности всех граждан страны в будущие преобразования, подчеркивая необходимость совместных усилий.

Повторы: we have never, ever, ever, ever failed in America when we've acted together.

Антитезы: in peace and in war we've come so far.

Фонетические средства, такие как ассонанс и аллитерация: through storm and strife.

Джо Байден отмечает, что без единства страна погрузится в хаос: no nation, only a state of chaos.

Также Джо Байден много говорил о победе демократии, используя метафоры и синтаксические повторы: we've learned again that democracy is precious, democracy is fragile and, at this hour my friends, democracy has prevailed.

Джо Байден использует распространенный в политических выступлениях анадиплосис: This is America's day. This is democracy's day. A day of history and hope, of renewal and resolve. $\mathrm{C}$ помощью этого стилистического приема он подчеркивает особенность дня его инаугурации и триумф демократии.

В своем выступлении он, как демократ, часто поднимает вопросы расизма и равноправия. Джо Байден использует параллелизм: a cry for racial justice... a cry for survival... a cry that can't be any more desperate or any more clear now, a также антитезу: the battle is perennial and victory is never secure. $\mathrm{OH}$ подчеркивает, что битва за равенство в стране продолжается очень давно, но победа никогда не бывает окончательной.

Также он обыгрывает словосочетание «civil war»: we must end this uncivil war that pits red against blue, rural versus urban, conservative versus liberal. Он называет внутренние столкновения в стране «нецивилизованной войной», отмечая, что они принимают все более агрессивный характер и ведут к расколу и 
гражданской войне. Дальше он использует антитезу, предлагая открыть души вместо того, чтобы ожесточить сердца: we can do this if we open our souls instead of hardening our hearts.

Не обошел Джо Байден в своей инаугурационной речи и вопрос коронавируса, сравнив его с охотником, идущим по пятам: a once in a century virus that silently stalks the country. $\mathrm{C}$ помощью повторяющегося словосочетания «much to» Джо Байден отмечает, как много необходимо сделать, чтобы в стране закончилась эта зима, таящая в себе множество угроз:

We have much to do in this winter of peril.

Much to do, much to heal, $\underline{\text { much to }}$ restore, much to build and much to gain.

Говоря о международных отношениях Джо Байден использует редкий стилистический прием - хиазм: and we'll lead not merely by the example of our power but the power of our example.

Подразумевая своего предшественника Джо Байден использует метафору, сравнивая политику с бушующим огнем, сжигающим все на своем пути: politics doesn't have to be a raging fire destroying everything in its path.

Завершая свое выступление Джо Байден с помощью повтора еще раз подчеркивает, что будет президентом для всех американцев, независимо от цвета кожи, партии, обеспеченности: I will be $\underline{a}$ President for all Americans, all Americans. Примечательно также использование неопределенного артикля в этом предложении, которое можно перевести как «одним из». С помощью противопоставления политик подчеркивает необходимость объединения всех американцев для того, чтобы писать новую историю страны: American story of hope, not fear. Of unity not division, of light not darkness. Также он сравнивает США с маяком для всего мира: that America secured liberty at home and stood once again as a beacon to the world.

Таким образом, можно сделать вывод о том, что в своей инаугурационной речи Джозеф Байден чаще всего использовал языковую игру на синтаксическом уровне. В его выступлении превалировали различные повторы и параллельные конструкции, которые подчеркивали его настрой и придавали уверенность его словам, помогая адресантам проникнуться и довериться новому президенту. Фонетические приемы, представленные ассонансом и аллитерацией, придают речи ритмичность. Также большой 
частотой употребления отличаются лексические приемы, представленные в основном метафорами или цитатами, с помощью которых Джо Байден взывает к положительной реакции реципиентов и имплицитно озвучивает курс, по которому пойдет страна в ближайшее время, а также проблемы, с которыми она столкнулась.

\section{ЛИТЕРАТУРА}

1. Витгенштейн Л. Философские исследования // Витгенштейн Л.: Избр. Философские работы. Москва: Гнозис, 1994, Ч. 1. - 612 с.

2. Гридина Т. А. Ассоциативный потенциал слова и его реализация в речи: явление языковой игры. Диссертация ... доктора филологических наук. Москва, 1996. - 566 с.

3. Нухов С.Ж. Языковая игра в английском словообразовании: имя прилагательное. Монография. - Уфа: РИЦ БашГУ, 2016. - 176 с.

4. Санников В. 3. Русский язык в зеркале языковой игры. - Москва: Языки славянской культуры, 2002. $-552 \mathrm{c}$.

1. Crystal D. Language Play. - Chicago: The University of Chicago Press, 2001. - 249 p.

2. Farb P. Word Play: What Happens When People Talk. - New York: Knopf, 1974. - 421 p.

3. Full transcript of Joe Biden's inauguration speech [Электронный pесурс]. URL: https://www.bbc.com/news/world-us-canada55656824 (дата обращения: 14.04.2021).

(C) Ясакова Ю.С., 2021 г. 